\title{
Drone production and drone comb utilization in colonies of the African honey bee, Apis mellifera scutellata Lepeletier, in Africa
}

\author{
LC McNally †, SS Schneider * \\ Department of Biology, University of North Carolina at Charlotte, Charlotte, NC 28223, USA
}

(Received 4 November 1993; accepted 21 June 1994)

\begin{abstract}
Summary - Drone production and drone comb utilization were investigated in naturally occurring colonies of the African honey bee, Apis mellifera scutellata, in the Okavango River Delta, Botswana. Drone production occurred primarily in larger, thriving and swarming colonies that contained large proportions of worker brood, and by inference were experiencing a period of growth. Drone production was rarely observed in smaller, newly established colonies, or larger colonies with reduced worker brood rearing. Maximum drone production occurred in September-October, and coincided with the swarming season and the period of peak resource abundance. Drone production occurred sporadically throughout the remainder of the year. Food storage in drone comb was lowest from July-October (when colonies concentrated on brood production), and low and variable throughout the remainder of the year.
\end{abstract}

\section{Apis mellifera scutellata / drone / drone comb / brood / Africa}

\section{INTRODUCTION}

Drone production is an important part of the reproductive biology of the honey bee, Apis mellifera. Drones mate with virgin queens; however, they perform no other functions in the colony and, in fact, may place a burden on colony growth (Seeley, 1985). Drones tend to be produced only when colony resources are sufficient and queens are available for mating. Drone production therefore is typically associated with swarming and is influenced by some of the same factors that affect swarming behavior (Allen, 1958; Winston, 1987). Both swarming and drone production are dependent upon forage availability, because ample food resources are necessary to stimulate the period of rapid colony growth that precedes reproductive swarming (Fletcher, 1978; Seeley, 1985; Winston, 1987). In addition, drone production may be influenced by colony

* Correspondence and reprints

† Present address: Biology Department, Davidson College, PO Box 1719, Davidson, NC 28036, USA 
size, since the foraging force of smaller colonies may be unable to provide sufficient resources for the rearing and maintenance of drones (Winston, 1987).

There has been increased interest in the factors influencing drone production following the introduction of the African honey bee race, Apis mellifera scutellata, in South America in 1956. Differences in the biology of drones in $A m$ scutellata and temperate honey bee races may have contributed to the establishment and rapid spread of the Africanized bee population in the neotropics (Fletcher, 1991). The extended foraging season in the tropics allows tropical colonies to swarm and raise drones throughout much of the year (Fletcher, 1978; Rinderer et al, 1987; Winston, 1987, 1992). In contrast, temperate honey bees typically swarm and produce drones primarily during the spring and summer months when resources are abundant (Seeley, 1985; Winston, 1987). Furthermore, colonies of tropical honey bees have a higher rate of reproductive swarming and produce proportionately more drones than do similar-sized colonies in temperate climates (Fletcher, 1978; Winston et al, 1983; Winston, 1987, 1992). In the neotropics this increases the chance of European queens mating with African drones, thereby resulting in Africanized progeny (Rinderer et al, 1987; Fletcher, 1991; Winston, 1992). Reproductive parasitism by Africanized drones may also enhance the spread of the Africanized bee. Africanized drones tend to migrate into European honey-bee colonies, which may inhibit European drone production thereby giving Africanized drones a mating advantage (Rinderer et al, 1985; Danka and Rinderer, 1988).

Thus, a better understanding of the biology of tropical honey bees and the Africanized bee requires a knowledge of the factors influencing drone production. To date, much of what is known on this topic has come from studies of the Africanized bee in Central and South America. However, patterns of drone production in African honey bees are most likely the result of selective forces associated with the native African environment. Yet, little is known about the biology of drones in Africa.

The purpose of this study was to examine drone production and drone comb use in naturally occurring colonies of the African honey bee, $A m$ scutellata, in Africa. The objectives of the study were to: (1) determine the amount of drone comb in $A \mathrm{~m}$ scutellata colonies; (2) examine seasonal patterns of drone production and the utilization of drone comb for food storage; and (3) examine how drone production and drone comb utilization may be associated with patterns of colony growth and development and of resource availability. When possible, the results of the present study were compared with studies of drone biology of Africanized honey bees in the neotropics.

\section{METHODS AND MATERIALS}

\section{Study area}

The study was conducted from August to December 1986 and from October 1989 to July 1990 in the Okavango River Delta, Botswana. The Okavango occupies approximately $17000 \mathrm{~km}^{2}$ and is sparsely inhabited by humans. There are no beekeeping and few agricultural practices in the Okavango and no foreign races of honey bees have been introduced (Schneider and Blyther, 1988). A $m$ scutellata colonies in the Delta are abundant (approx 8/km²; Schneider and Blyther, 1988). The annual colony cycle consists of 3 fairly distinct seasons, which are associated with seasonal fluctuations in resource availability. The reproductive swarming season occurs from October-November at the end of the period of peak floral abundance. The reproductive swarming season is followed by the absconding (migration) season (November-May), during which resource availability is reduced and variable. The migration season is followed by an establishment period (June-September), in which large numbers of colonies move into the study area during and 
slightly preceding the period of peak resource abundance (McNally and Schneider, 1992).

The study site in 1986 was located on the east bank of the Santantadibe River (19 $34.59^{\prime} \mathrm{S} ; 23^{\circ}$ $22.74^{\prime} E$ ), while the site for $1989-1990$ was located on the edge of a large lagoon ( $19^{\circ} 35.42^{\prime} \mathrm{S} ; 23^{\circ}$ $21.43^{\prime} \mathrm{E}$ ). Further descriptions of the study area and the nesting biology of $A m$ scutellata in the Okavango are provided in Schneider and Blyther (1988) and McNally and Schneider (1992).

\section{Determining patterns of colony development, drone production and comb usage}

Colony development, drone production and patterns of comb usage were examined by dissecting a mean \pm SE of $9.1 \pm 1.1$ (range $3-17$ ) naturally occurring $\boldsymbol{A} m$ scutellata nests in the field each month. For each dissected colony, all combs were removed and the following were determined: (1) total comb area (in $\mathrm{cm}^{2}$ ); (2) the proportion of total comb area containing worker brood (eggs, larvae, and pupae); (3) total drone comb area (in $\mathrm{cm}^{2}$ ); and (4) the proportion of drone comb devoted to drone brood (eggs, larvae, and pupae), to food (honey, nectar, and pollen), and that was empty. Drone comb was identified as comb having slightly larger cells (Seeley, 1985). Comb areas in 1989-1990 were estimated using a grid of $5 \times 5$ $\mathrm{cm}$ squares; those in 1986 were estimated by weighing sketches drawn to scale using mean values of comb height and width (see Schneider and Blyther, 1988, for further details of comb measurement procedures).

The association between drone production and colony size was examined indirectly by determining the relationships between comb areas of drone brood, total comb areas, and comb areas containing worker brood. We did not examine the relationship between drone production and colony size directly by killing and counting the number of adult workers and drones, because captured colonies were utilized in other portions of the research. We estimated the number of drones produced in each colony by converting the comb areas containing drone brood into the number of cells containing eggs, larvae, and pupae, using the value of 2.65 African drone cells per $\mathrm{cm}^{2}$ (based on data provided by Fletcher, 1978).

In addition to estimating the different comb areas, we also classified each dissected colony as newly established, swarming, associated with seasonal absconding, or thriving, following the methods of Schneider and McNally (this issue). We subsequently examined the relationship between drone comb areas, drone brood production and the different stages of colony development.

\section{Determining seasonal patterns of resource availability}

Resource availability was estimated by conducting monthly vegetational surveys of the number of blooming trees, shrubs, and herbaceous annuals ('weeds'). Surveys of trees and shrubs were conducted by establishing twenty $1000 \mathrm{~m}^{2}$ vegetational plots, scattered over a $15 \mathrm{~km}^{2}$ area and separated from one another by at least $500 \mathrm{~m}$. Surveys of weeds were conducted by establishing $8050-\mathrm{m}$ line transects, 40 located within the 20 vegetational plots ( 2 per plot) and 40 in adjacent grassland areas. Each month, we recorded the number of each species of blooming tree, shrub, and weed. Each species was assigned a 'bloom value' using the following scale for the estimated number of flowers per plant: $1(1-100)$; 2 (101-500); 3 (501-1 000); 4 (1 001-2 000); 5 $(>2000)$. A mean bloom value was then calculated for trees and shrubs over all plots and for weeds over all transects for each month of the year. These mean values provided monthly indices of the abundance of floral resources (see McNally and Schneider, 1992, for further details of estimating resource availability). At present, little is known about the degree to which $A m$ scutellata visits the different blooming species in the Okavango (Schneider and Blyther, 1988; McNally and Schneider, 1992). Thus, our mean monthly bloom values provide estimates of potential forage abundance, and not the actual utilization of floral resources.

All statistical analyses were conducted using 2-tailed levels of significance. Proportional data for drone comb areas were arcsine transformed prior to analysis. All mean values are reported as \pm 1 SE.

\section{RESULTS}

A total of 109 nests were dissected during the 12 months of the study. Of these, 29 
were newly established, 13 were associated with reproductive swarming, 45 were thriving, and 22 were associated with seasonal absconding. Two of the newly established nests contained no comb, and 1 thriving colony was too damaged during the dissection process to allow for reliable measurements of comb areas. The latter 3 nests were not used in the analyses and thus the results reported refer to the remaining 106 nests.

Of the 106 nests, $59(56 \%)$ contained drone comb, and such comb consistently represented a small proportion of total comb area (mean drone comb area, $649 \pm 83 \mathrm{~cm}^{2}$; mean proportion of total comb, $8.3 \pm 0.7 \%$ ). However, the amount of drone comb present was influenced by (1) the stage of colony development, and (2) the colony size, as inferred from total comb area.

Of the 27 newly established colonies examined, only 4 contained drone comb. In contrast, drone comb was observed in 54 of the 79 more established colonies (those that were swarming, thriving, or absconding; $\chi^{2}=21.3 ; d f=1 ; P<0.001$ ). Among the established nests, the presence of drone comb was related to colony size. The mean total comb area for the 54 colonies with drone comb (7 $\left.578.7 \pm 597.8 \mathrm{~cm}^{2}\right)$ was more than twice the $2844.8 \pm 296.3 \mathrm{~cm}^{2}$ observed for the 25 without drone comb ( $t=$ 5.27; $P<0.01$ ). Indeed, as a general rule drone comb was not constructed until colonies contained a total of $4000-5000$ $\mathrm{cm}^{2}$ of comb.

Examinations of drone production and drone comb utilization were restricted to 51 of the 59 total colonies that contained drone comb. Of the remaining 8 colonies, 4 were queenless and declining and 4 had absconded and contained only empty comb. Drone brood was observed in $18(35.3 \%)$ of the 51 nests examined. These 18 colonies devoted $65.4 \pm 6.8 \%$ of drone comb to drone brood, and contained $1004 \pm 241$ developing drones.
Drone production occurred throughout much of the year, and seasonal patterns were related to the annual colony cycle of $A$ $m$ scutellata in the Okavango. Maximum drone production occurred in September-October, and coincided with the end of the establishment period and the first portion of the swarming season ( $f i g 1 \mathrm{~A}$ ). Of the 14 nests dissected during these months that contained drone comb, 11 had drone brood. These colonies devoted $76.6 \pm 6.0 \%$ of drone comb area to the rearing of drones, and contained $1383 \pm 342$ developing drones (fig 1B). Drone production declined in November at the onset of the absconding season, and remained low and sporadic throughout the rest of the year (fig 1A). Of the 37 nests dissected from NovemberAugust that contained drone comb, 7 had drone brood. The mean proportion of drone comb containing brood during these months was only $9.1 \pm 3.8 \%$, and colonies contained a mean of $77 \pm 36$ developing drones (fig 1B).

Drone production was influenced by: (1) seasonal fluctuations in resource availability; (2) the stage of colony development; and (3) patterns of colony growth. When viewed over all months of the study, there was a significant correlation between the mean proportion of drone comb area containing brood and the monthly bloom values for trees and shrubs $(r=0.797, N=12$, $P<0.002 ;$ fig $1 \mathrm{~A}$ and $\mathrm{C}$ ). Drone production was not associated with the availability of blooming weeds $(r=0.287, N=8, P>0.05$; fig $1 A$ and $C$ ).

Drone production occurred primarily in thriving and swarming colonies. Of the 18 colonies with drone brood, 13 were thriving, 3 were swarming, 2 were newly established, and none were associated with seasonal absconding ( $\chi^{2}$ comparing thriving and swarming versus newly established and absconding colonies; $P<0.01$ ).

Increased drone brood production was strongly associated with greater worker 

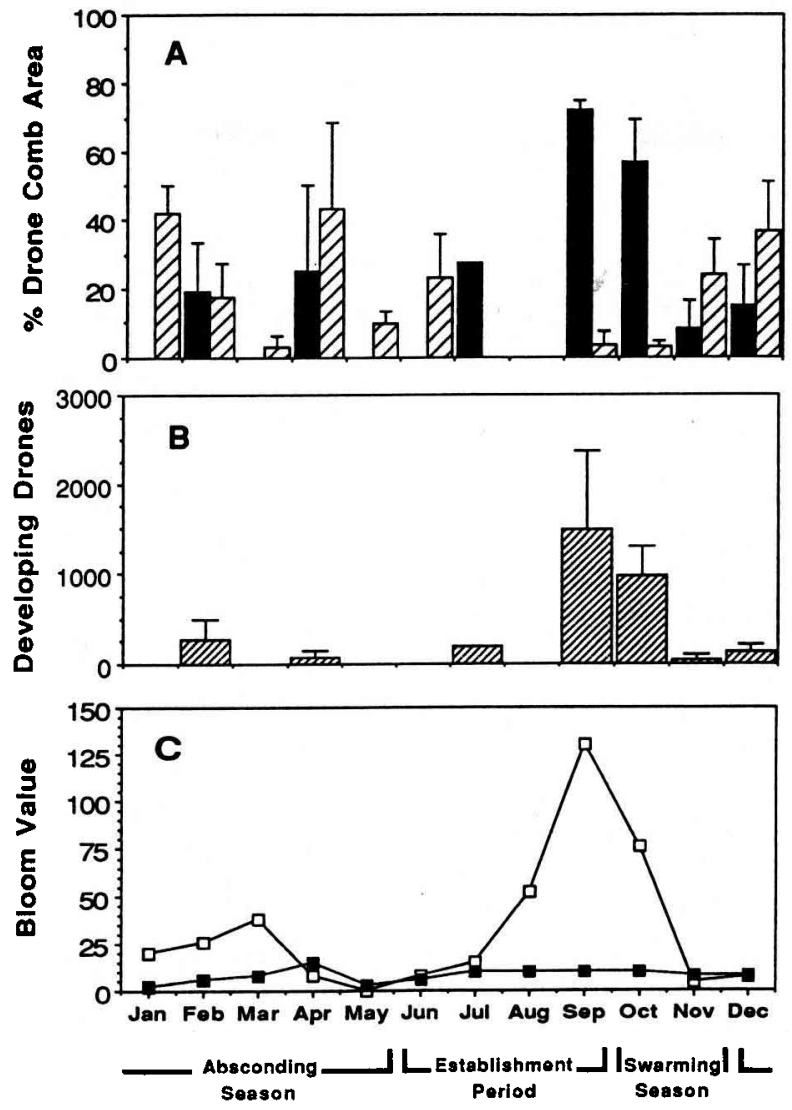

Fig 1. (A) Mean \pm SE proportion of total drone comb area devoted to drone brood rearing (closed bars) and food storage (hash-marked bars) for each month of the year, based on the 51 dissected colonies that contained drone comb (mean \pm SE dissected colonies per month, $4.2 \pm 0.7$; range, $1-11$ ). Only one colony dissected in August contained drone comb, all of which was empty. (B) Mean \pm SE number of developing drones (eggs, larvae, pupae) for each month of the year, based on the 51 dissected colonies that contained drone comb. (C) Mean bloom values for each month of the study for trees and shrubs (open squares), and herbaceous annuals (weeds; closed squares). Data on the abundance of blooming weeds were not available for July-October.

brood production, and by inference periods of colony growth. The mean proportion of total comb area devoted to worker brood in the 18 colonies that contained drone brood $(60.4 \pm 4.0 \%)$ was more than twice that of the 33 colonies that contained drone comb but no drone brood $(25.0 \pm 9.5 \% ; t=5.49$; $P<0.01)$. The observed relationship between worker and drone brood production may have been influenced by the inclusion in the analysis of 9 colonies that were preparing for seasonal absconding, because all of these contained no drone brood and little worker brood. However, if these 9 nests were excluded the mean proportion of comb area devoted to worker brood in the colonies 
without drone brood $(29.5 \pm 5.6 \%)$ was still significantly less than that of the colonies with drone brood $(t=4.20 ; P<0.01)$.

Unlike the proportion of drone comb, drone brood production was not associated with total comb area. The mean total comb area of the 18 nests containing drone brood $\left(8677 \pm 1124 \mathrm{~cm}^{2}\right.$ ) did not differ from that of the remaining 33 nests which had drone comb but no drone brood $\left(6574 \pm 684 \mathrm{~cm}^{2}\right.$; $t=1.69 ; P>0.05)$. Likewise, in the 18 nests with drone brood, there was no correlation between total comb area and the proportion of drone comb containing brood $(r=$ $0.018 ; P>0.05$ ). Thus, while drone comb tended to occur in the larger colonies, the raising of drone brood within the larger nests may have depended upon patterns of resource availability and colony growth.

Of the colonies that contained drone comb, $28(54.9 \%)$ used a portion of such comb for food storage during at least a part of the year. When viewed over all months, food storage accounted for $17.0 \pm 3.4 \%$ of drone comb area. Food storage was lowest from July-October, which included the period of maximum drone production (fig 1A). Of the 16 nests containing drone comb excavated during these months, $25.0 \%$ had food stored in drone comb and food storage accounted for a mean of $2.8 \pm 1.4 \%$ of total drone comb area. There was a greater use of drone comb for food storage throughout the remainder of the year (fig 1A). Of the 35 colonies excavated during November-June, $68.6 \%$ had food stored in drone comb and food storage accounted for 23.5 $\pm 4.4 \%$ of total drone comb area. However, there was considerable month-to-month variability in such use of drone comb (fig 1A). Forage availability was reduced and variable during the months of November-June (fig $1 \mathrm{C}$ ), which may have contributed to the erratic pattern of food storage observed in A m scutellata colonies at this time.

\section{DISCUSSION}

The results of this study suggest 3 main, interrelated characteristics of drone production and drone comb use by $A$ m scute/lata in the Okavango Delta. First, drone production was strongly influenced by patterns of colony growth and development. Drone comb and drone brood were observed primarily in larger, thriving and swarming colonies that contained large proportions of worker brood and were experiencing periods of growth. Newly established and smaller colonies rarely contained drone comb or drone brood, and larger colonies with reduced worker brood rearing did not contain drone brood even if drone comb was present. A relationship between drone production and increased colony growth and size also has been observed for temperate climate honey bees (Lee and Winston, 1985). However, this relationship has received little systematic investigation in Africanized colonies in the neotropics. The mean proportion of drone comb observed in the Okavango ( $8.3 \%$ ) was similar to the $5.9 \%$ reported for Africanized colonies in Mexico (Ratnieks et al, 1991), suggesting that levels of drone production may also be similar in the 2 environments. However, many of the colonies examined by Ratnieks et al were small and newly established, and at present it is unknown how drone production changes with colony growth and development in Africanized bees.

A second characteristics suggested by our results was that drone production occurred primarily during a relatively brief period (September and October), but then continued at low, sporadic levels throughout the remainder of the year. The period of peak drone production coincided with the swarming season and the end of the period of greatest forage availability. This is also the period of maximum worker brood production and the time in which most new queens are reared (McNally and Schnei- 
der, 1992; Schneider and McNally, 1994). Thus, A $m$ scutellata colonies in the Okavango may capitalize on the period of peak floral abundance to increase rapidly in size, produce drones and then raise queens and swarm as resources begin to decline. Seasonal pattern of drone production in Africanized colonies are unclear. In French Guiana, Africanized colonies can produce reproductive swarms for 8 months of the year (August-April; Winston, 1980; Winston and Taylor, 1980). However, the peak periods of drone production for such colonies have not been determined.

The low, sporadic production of drones from November-June may have been associated with the rearing of replacement queens during this period. Replacement queens are produced when colonies suddenly lose their mated queen due to predation, disease, or some other factor (Winston, 1979). Queen replacement in African colonies may be common. Up to $40 \%$ of colonies in South Africa lose their queens each year (Fletcher and Tribe, 1977; Fletcher, 1978). A m scutellata colonies in the Okavango experience high predation rates (Schneider and Blyther, 1988), which may result in increased queen loss. A high incidence of replacement queen rearing may favor some continued level of drone production nearly all year, provided that colony size and development are conducive. Africanized colonies in the neotropics also produce drones throughout much of the year (Rinderer et al, 1987; Winston, 1987).

The third characteristic observed for drone comb in the Okavango colonies was that such comb was utilized to store both honey and pollen. However, food storage in drone comb tended to occur at low, sporadic levels. Overall, food storage accounted for only $17 \%$ of total drone comb area throughout the year. Food storage within drone comb fluctuated with both drone brood production and forage availability. The pro- portion of drone comb containing food tended to decrease during periods of drone brood production and increase when forage was abundant. No data are available on the utilization of drone comb for food storage in naturally occurring Africanized colonies.

In summary, drone production and drone comb use in $A$ m scutellata colonies of the Okavango fluctuated with patterns of colony growth and development. Maximum drone production occurred in larger, growing colonies, primarily during a relatively brief period of resource abundance. However, colonies in the Okavango, and Africanized colonies in the neotropics also produce drones at low levels throughout much of the year. Continued drone production may be linked with the dynamics of queen production and may have contributed to the rapid spread and possible reproductive advantage of the Africanized bee in the neotropics.

\section{ACKNOWLEDGMENTS}

The comments of 2 anonymous reviewers greatly improved the manuscript. We thank Koro Safaris of Maun, Botswana for help in locating and establishing the study sites. C and G Blomstrand of Thamalakane Lodge provided much appreciated hospitality and moral and logistical support. The Office of the President, the Department of Wildlife and Tourism, and the National Museum and Art Gallery of Botswana provided valuable assistance throughout the study. We give special thanks to our local assistants, Kenneth, Longwan and James. The research was supported by US National Science Foundation, grant BSR 8906997, Fulbright Grant No 85-42174, and a grant from the Whitehall Foundation.

Résumé - Production de mâles et utilisation des rayons de mâles par les colonies d'abeilles africaines, Apis mellifera scutellata Lepeletier, en Afrique. La production de mâles et l'utilisation des rayons de mâles a été étudiée sur 12 mois dans des colonies naturelles de l'abeille africaine 
A $m$ scutellata dans le delta de l'Okavango au Botswana. Chaque mois des nids $(9,1 \pm$ 1,1 en moyenne) étaient prélevés dans la nature et les paramètres suivants étaient déterminés : surface totale des rayons, surface de couvain d'ouvrières, surface de couvain de mâles et proportions de rayons de mâles comportant du couvain et de la nourriture. En outre, chaque mois la végétation était observée afin de noter les ressources florales disponibles. Au total 109 nids ont été prélevés parmi lesquels 106 ont fourni des données exploitables. Cinquant-neuf de ces nids (56\%) renfermaient des rayons de mâles, mais ils ne représentaient qu'une petite proportion de la surface totale des rayons : $649 \pm 83 \mathrm{~cm}^{2}$, soit $8,3 \pm 0,7 \%$. Seules les colonies établies renfermaient des rayons de mâles, les colonies récemment fondées, rarement. La quantité de rayons de mâles dans les colonies établies était significativement et positivement corrélée avec la surface totale de rayons. L'analyse de l'utilisation des rayons de mâles a été limitée à 51 colonies florissantes parmi les 59 qui renfermaient des rayons de mâles (les 8 restantes étaient orphelines et dépérissaient ou bien elles avaient déserté avant d'être prélevées). Le couvain de mâles a été observé dans 18 $(35,3 \%)$ des colonies possédant des rayons de mâles. Elles consacraient $65,4 \pm 6,8 \%$ des rayons de mâles au couvain de mâles et renfermaient $1004 \pm 241$ mâles en développement. Le maximum de la production de mâles s'est situé en septembre et octobre (fig $1 \mathrm{~A}$ ) et a coïncidé avec la période d'essaimage et la période de floraison maximum. Durant ces mois, $78 \%$ des nids disséqués qui renfermaient des rayons de mâles possédaient du couvain de mâles. Ces colonies consacraient 76,6 $\pm 6,0 \%$ de la surface de rayons de mâles à l'élevage de mâles et renfermaient $1383 \pm$ 342 mâles en développement (fig 1B). Pendant tout le reste de l'année la production de mâles a été faible et sporadique (fig $1 \mathrm{~A}$, B). La production de mâles étaient signifi- cativement corrélée avec la floraison des arbres et des buissons, mais pas avec celle des plantes herbacées (fig 1A, C) et associée à l'augmentation de l'élevage du couvain d'ouvrières. La proportion moyenne de la surface totale de rayons consacrée au couvain d'ouvrières dans les 18 colonies qui comportaient du couvain de mâles $(60,4 \pm 4,0 \%)$ était plus du double de celle des 33 colonies qui renfermaient des rayons de mâles mais pas de couvain de mâles $(25,0 \pm 9,5 \%)$. Vingt-huit $(54,9 \%)$ des 51 colonies florissantes utilisaient les rayons de mâles pour les réserves de nourriture, mais celles-ci ne représentaient que $17,0 \pm 3,4 \%$ de la surface totale de rayons mâles (fig 1). En résumé ont peut dire que la production de mâles survient principalement dans les colonies fortes et bien établies qui produisent beaucoup de couvain d'ouvrières. Le fait que la production maximale de couvain de mâles ait lieu durant la période d'essaimage peut être relié à la plus grande disponibilité en reines vierges et en ressources florales pendant cette période. La production continue tout au long de l'année peut être mise en relation avec l'élevage de reines de remplacement, puisque chez les colonies africaines les pertes de reines sont élevées.

\section{Apis mellifera scutellata/ production de mâles / Afrique}

\section{Zusammenfassung - Erzeugung von Drohnen und Nutzung der Drohnenwa- ben in Völkern der afrikanischen Honig- biene, Apis mellifera scutellata Lepeletier} (1836), in Afrika. Die Drohnenproduktion und die Nutzung der Drohnenwaben wurde während einer Periode von 12 Monaten bei wilden Völkern der afrikanischen Biene Apis mellifera scutellata im Delta des Okavango Flusses in Botswana untersucht. Jeden Monat wurden im Mittel 9,1 $\pm 1,1$ Nester in der Umgebung ausgegraben. Die Gesamtfläche der Waben, die Fläche der Arbeite- 
rinnenbrut, die Fläche der Drohnenwaben und das Verhältnis von Brut zu Honig in der Drohnenwabe wurden bestimmt. Zusätzlich wurde jeden Monat die Vegetation begutachtet, um das Vorhandensein der Tracht an Blüten abzuschätzen. Insgesamt wurden 109 Nester ausgegraben, davon waren 106 zur Datenerhebung geeignet. 56\% der Nester enthielten Drohnenwaben, aber diese Waben bildeten nur einen kleinen Anteil der Gesamtfläche der Waben (mittlere Fläche der Drohnenwaben: $649 \pm 83$ $\mathrm{cm}^{2}$, mittlerer Anteil an der Gesamtwabenfläche: $8,3 \pm 0,7 \%$ ). Drohnenwaben kamen in der Regel nur in etablierten Völkern vor, in neu gegründeten Nestern waren sie selten. Die Anzahl der vorhandenen Drohnenwaben in etablierten Völkern korrelierte signifikant und positiv mit der Gesamtfläche der Waben. Die Analyse der Nutzung der Drohnenwabe wurde auf 51 von 59 starken Völkern beschränkt, die Drohnenwaben enthielten (die 8 Völker, die nicht berücksichtigt wurden, waren entweder weisellos und wurden dadurch schwächer oder sie hatten kurz vor der Ausgrabung das Nest verlassen). Drohnenbrut gab es in 18 Völkern $(35,3 \%)$. In diesen Völkern war $65,4 \%$ der Drohnenwabe bebrütet und enthielten $1004 \pm 241$ Zellen mit Larven und Puppen. Das Maximum der Drohnenproduktion lag im September und Oktober (Abb 1A) und fiel mit der Schwarmzeit und der Zeit der größten Blütentracht zusammen. In dieser Zeit nutzten die Völker $76,6 \pm 6,0 \%$ der Drohnenwaben für die Aufzucht von Drohnen und enthielten $1383 \pm 342$ Zellen mit Brut. Auf einem niedrigem, sporadischem Niveau wurden Drohnen während das ganzen Jahres erzeugt (Abb 1A, B). Die Erzeugung von Drohnen war signifikant korreliert mit der Verfügbarkeit von blühenden Bäumen und Büschen $(A b b 1, C)$ und war mit einem Anstieg der Arbeiterinnenbrut verbunden. Der durchschnittliche Anteil der Gesamtwabenfläche der 18 Völker, die Drohnenbrut $(60,4 \pm 4 \%)$ enthielten, war mehr als doppelt so hoch wie das der 33 Völker, die zwar Drohnenwaber, aber keine Drohnenbrut hatten $(25,0 \pm 9,5 \%)$. Achtundzwanzig $(54,9 \%)$ der 51 starken Völker benutzten die Drohnenwaben als Nahrungsspeicher, obwohl im Durchschnitt nur 17,0 $\pm 3,4 \%$ der Gesamtfläche der Drohnenwabe als Futterspeicher genutzt wurde (Abb 1). Zusammenfassend läßt sich sagen, daß Drohnenproduktion vorwiegend in starken, gut etablierten Völkern mit hoher Produktion von Arbeiterinnenbrut vorkommt. Sie fällt also in die Zeit des starken Volkswachstums. Das Maximum der Drohnenproduktion während der Schwarmzeit könnte mit dem häufigeren Vorkommen von unbegatteten Königinnen und von Trachtquellen in dieser Zeit zusammenhängen. Die fortgesetzte geringfügige Drohnenproduktion während des ganzen Jahres mag mit der ständigen Aufzucht von Ersatzköniginnen zusammenhängen, da es in afrikanischen Bienenvölkern einen hohen Verlust von Königinnen gibt.

\section{Apis mellifera scutellata / Drohnenpro- duktion / Afrika}

\section{REFERENCES}

Allen MD (1958) Drone brood in honey bee colonies. $J$ Econ Entomol 51, 46-48

Danka RG, Rinderer TE (1988) Social reproductive parasitism by Africanized honey bee. In: Africanized Honey Bees and Bee Mites (GR Needham, RE Page, Jr, M Delfinado-Baker, CE Bowman, eds) Ellis Horwood Ltd, Chichester, UK, 214-222

Fletcher DJC, Tribe GD (1977) Swarming potential of the African bee, Apis mellifera adansonii L. In: African Bees: Taxonomy, Biology and Economic Use (DJC Fletcher, ed) Apimondia, Pretoria, South Africa, 2534

Fletcher DJC (1978) The African bee, Apis mellifera adansonii, in Africa. Annu Rev Entomol 23, 151-171

Fletcher DJC (1991) Interdependence of genetics and ecology in a solution to the African bee problem. In: The 'African' Honey Bee (M Spivak, DJC Fletcher, MD Breed, eds) Westview Press, San Francisco, CA, USA, 77-94

Lee PC, Winston ML (1985) The effect of swarm size and date of issue on comb construction in newly 
founded colonies of honeybees (Apis mellifera L). Can J Zool 63, 524-527

McNally LC, Schneider SS (1992) Seasonal cycles of growth, development and movement of African honey bee, Apis mellifera scutellata, in Africa. Insectes Soc 39, 167-179

Ratnieks FLW, Piery MA, Cuadriello I (1991) The natural nest and nest density of the Africanized honey bee (Hymenoptera, Apidae) near Tapachula, Chiapas, Mexico. Can Entomol 123, 353-359

Rinderer TE, Collins AM, Hellmich RL II, Danka RG (1987) Differential drone production by Africanized and European honey bee colonies. Apidologie 18, $61-68$

Rinderer TE, Hellmich RL II, Danka RG, Collins AM (1985) Male reproductive parasitism: a factor in the Africanization of European honey-bee population. Science 228, 1119-1121

Schneider SS, McNally LC (1994) Developmental patterns associated with founding and swarming in colonies of the African honey bee race, Apis mellifera scutellata. Apidologie 25, 530-539

Schneider S, Blyther R (1988) The habitat and nesting biology of the African honey bee Apis mellifera scutel- lata in the Okavango River Delta, Botswana, Africa. Insectes Soc 35, 167-181

Seeley TD (1985) Honeybee Ecology. Princeton Univ Press, Princeton, NJ, USA

Winston ML (1979) Events following queen removal in colonies of Africanized honeybees in South America. Insectes Soc 26, 373-381

Winston ML (1980) Seasonal patterns of brood rearing and worker longevity in colonies of the Africanized honey bee in South America. J Kansas Entomol Soc $53,157-165$

Winston ML (1987) The Biology of the Honey Bee. Harvard Univ Press, Cambridge, MA, USA

Winston ML (1992) The biology and management of Africanized honey bees. Annu Rev Entomol 37, 173193

Winston ML, Taylor OR (1980) Factors preceding queen rearing in the Africanized honeybee (Apis mellifera) in South America. Insectes Soc 27, 289-304

Winston ML, Taylor OR, Otis GW (1983) Some differences between temperate European and tropical African and South American honeybees. Bee World 64, 12-21 